\title{
Electrochemical Sensors Based on Electropolymerized Films
}

\author{
Xu Qin, Hu Xiao-Ya and Hao Shi-Rong \\ College of Chemistry and Chemical Engineering, Yangzhou University
}

China

\section{Introduction}

Chemical sensors are the devices that provide a certain type of responses related to the quantity of a specific species. All chemical sensors consist of a transducer and a chemically selective layer. The transducers transform the response into a detectable signal on modern instrumentation, and the chemically selective layer isolates the response of the analyte from its immediate environment. According to the properties to be determined, chemical sensors can be classified as electrical, optical, mass or thermal sensors. Among all of them electrochemical sensors obtained more attention because they are sensitive and selective, fast and accurate, portable and in expensive.

The modification of electrodes surfaces by some special layers has been the major growth area in electrochemical sensors in recent years. Compared to conventional electrodes, greater control of electrode characteristics and reactivity is achieved by surface modification, since the immobilization transfers the physicochemical properties of the modifier to the electrode surface. This process could impart a high degree of selectivity or sensitivity to the electrochemical transducers. Different procedures such as chemical reaction, chemisorption, composite formation or polymer coating have been used to modify electrodes. Several papers have reviewed the application of the modified electrodes in electrochemical sensors areas [1]

Electrochemical polymerization (ECP) refers to the application of electrochemical methods in the cathode or anode during the polymerization reaction process. The polymerization method provides a new current or potential control factor, so some important advantages were recognized at the beginning of its development such as: short process and low cost. The film thickness and composition can be achieved easily by controlling the electrochemical parameters during the electrochemical process. In addition, electrochemical polymerization can make raw monomer aggregate directly on the substrate film to avoid the use of a large number of volatile organic solvents to achieve the aim of clean production. Because of these excellent features, electropolymerization method holds a promising future for construct simple design, high stable, rapid response and enhanced selectivity sensors. This review will briefly present the development and application of the sensors prepared by electropolymerization method in the recent ten years. The main goal of this contribution is not to collect all papers published recently, but to discuss the development and advantages of the electropolymerized films for analytical purpose. For application, we specifically focused on the most recent and promising applications of those sensors in environmental and clinical monitoring. 


\section{Classification of films obtained by electrochemical polymerization method}

Polymerization is a reaction in which large molecules are created from many small monomers. Normally it is a process which must be controlled carefully under strict conditions. Recently electropolymerization method has been successfully used for the controllable preparation of films because of the advantages we referred in the introduction section. Three types of electrochemical methods are generally employed for the polymerization of different monomers: (1) a constant current (galvanostatic); (b) a constant potential (potentiostatic) and (3) a potential scanning/cycling or sweeping. Different types of polymer films were applied for the construction of sensors. They are classified as conductive and nonconductive films.

\subsection{Conducting films prepared by electropolymerization method}

Conducting polymers have the polyconjugated structures with electronic properties similar to metals, but retaining the properties of conventional organic polymers. They have gained much attention in sensor areas [2,3] in recent years because of their unique characters [4]. A wide variety of organic molecules have been used as the monomers for the preparation of conducting polymers, such as polycyclic benzenoid, nonbenzenoid hydrocarbons, acetylene, polyaromatic and heterocyclic compounds. Fig. 1 gives some examples of the conductive

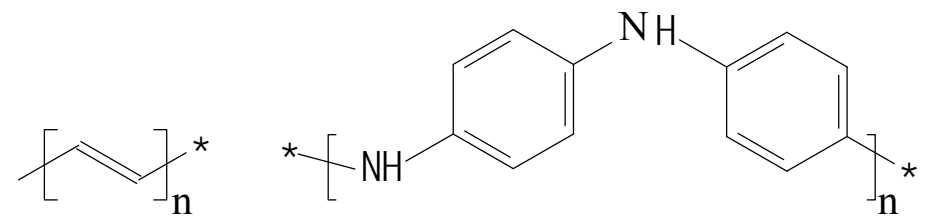

Polyacetylene

Polyaniline

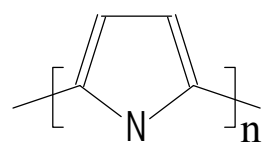

Polypyrrole

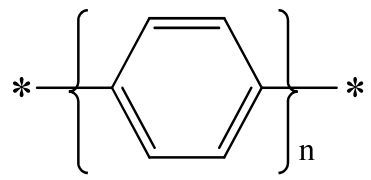

Poly(paraphenylene)

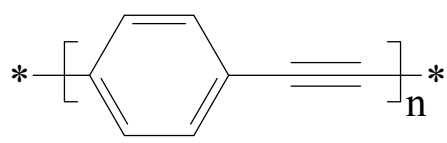

Poly(paraphenyleneethynylene)

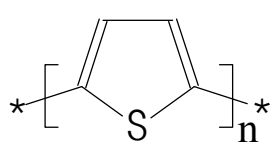

Polythiophene

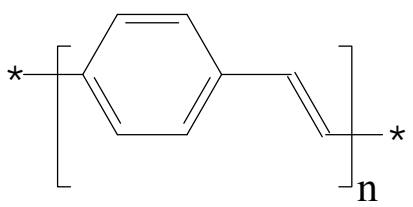

Poly(paraphenylenevinylene)

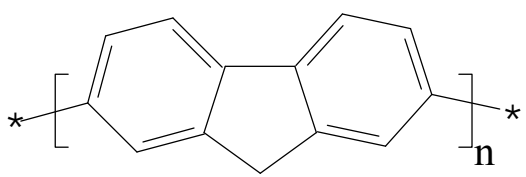

Polyfluorene 


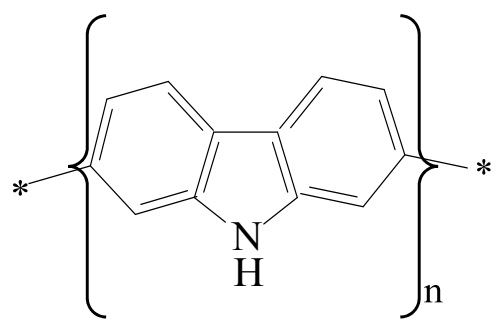

Polycarbazole

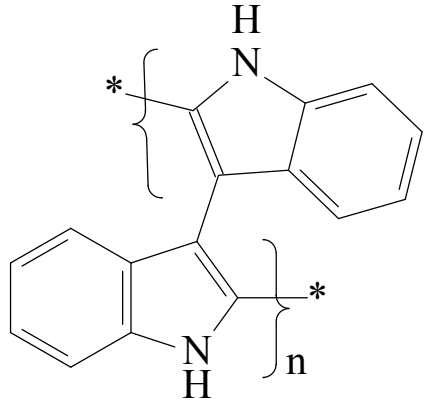

Polyindole

Fig. 1. Main chasses of conductive polymers

polymer films. Their unusual electrochemical properties are caused by the conjugated $\pi$ electron backbones. A large number of reviews devoted to the fabrication and description of the properties of conducting polymers have been published. Numbers of reviews focus on their use as electrochemical sensors. However there is still considerable interest in the development of new conductive polymers by the electropolymerization method, and new application of the films continually appear. Novel work in the literature from 2000 up to present will be reviewed.

\subsection{Non-conducting films prepared by electropolymerization method}

Non-conducting films prepared by electropolymerization method are also important. The resulting non-conducting film usually has a small thickness and is self-controlled by the increase in electrical resistance during its growth on the electrode. Because non-conducting polymers are always thin (10-100 $\mathrm{nm})$, substrates and products can diffuse rapidly to and from the film modified electrodes. Therefore, fast response time and high selectivity could be expected for non-conducting polymer based electrochemical sensors. In most cases, phenol and its derivates are always used for the synthesis of non-conductive films by electrochemical methods [5]. Fig. 2 illustrated the process for the preparing of the phenol related films. Phenylate will be oxidized to generate phenolate radicals which would couple together by ortho- or para- coupling way. Subsequent reactions produce oligomers and, finally, poly(phenylene oxide) films are polymerized on the surface of the electrode. Mahmoudian MR et al prepared poly (pyrrole-co-phenol) (co-PyPh) film by using cyclic voltammetry in the mixture electrolytes of dodecyl benzene sulphonic acid (DBSA) and oxalic acid solution on steel electrodes [6] . It can be used to protect the corrosion of steel. Tahar NB and Savall A[7] have studied the electrochemical oxidation of phenol at different temperatures in basic aqueous solution on a vitreous carbon electrode at different temperatures by cyclic voltammetry and chronoamperometry techniques. Other phenol derivatives have also been prepared by the electropolymerization method. Matsushita et al reported the electropolymerization of coniferyl alcohol in an aqueous system $(0.2 \mathrm{M} \mathrm{NaOH})$ and in an organic solvent system $\left[\mathrm{CH}_{2} \mathrm{Cl}_{2} /\right.$ methanol $(4: 1 \mathrm{v} / \mathrm{v})$ in the presence of $0.2 \mathrm{M}$ $\left.\mathrm{LiClO}_{4}\right][8]$. Ciriello $\mathrm{R}$ et al. investigated the electrosynthesis mechanism of 2-naphthol (2$\mathrm{NAP}$ ) in phosphate buffer at $\mathrm{pH} 7$ on Pt electrodes. The voltammetric behavior suggested the formation of a non-conducting polymer (poly(2-NAP)) through an irreversible electrochemical process complicated by 2-NAP adsorption and fast electrode passivation [9]. 
Non-conductive polymers obtained from amino acid or their derivates have also obtained particular interest because they bears specific groups which can interact with some electroactive species through the formation of covalent bonds between either the amino and aldehyde or amino and carboxyl groups. We have used cyclic voltammetric method to form the L-cysteine modified electrode for the detection of sinomenine [10] , dopamine [11], terbinafine [12] and adenine [13]. Cystein was electropolymerized on a glassy carbon electrode in $0.04 \mathrm{M} \mathrm{HCl}$ solution in the scan range from -1.20 to $2.60 \mathrm{~V}$ at the scan rate of 100 $\mathrm{mV} / \mathrm{s}[13]$.

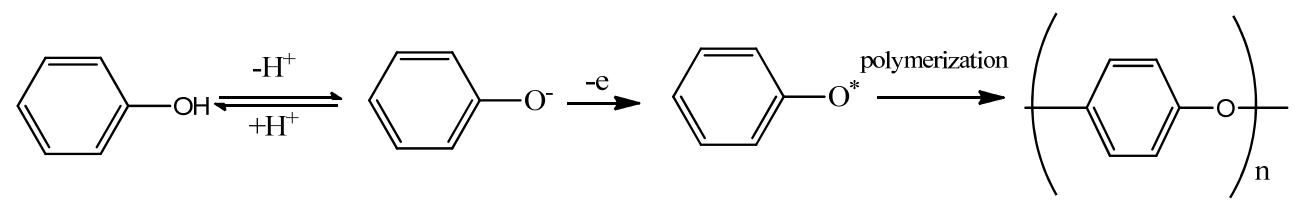

Fig. 2. The process for the preparing of the Phenol film by electrochemical method.

Fig. 3 illustrated the structures of some of the non-conductive films obtained by electropolymerization method. They included the already discussed polyphenol, polymers of phenylendiamines and the overoxidized polypyrrole (PPy). These polymers can be used as a novel support matrix for the immobilization of biomolecules to construct different electrochemical sensors. We would discuss the preparation and application of these films in the following section.

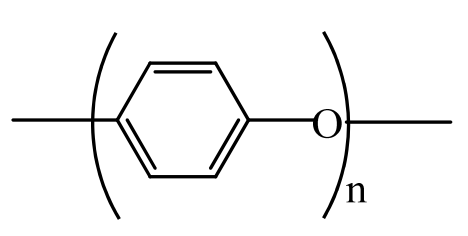

polyphenol

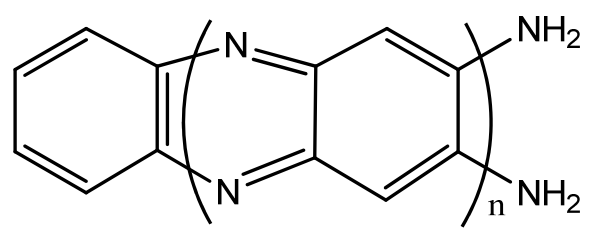

polyphenylendiamine

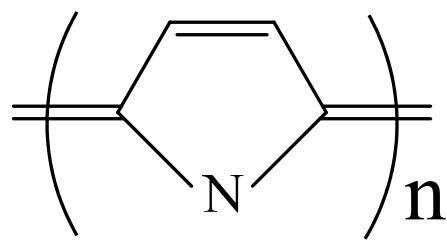

overoxidized polypyrrole

Fig. 3. Structures of some non-conductive polymerfilms

\section{Application of the electropolymerized film in analytical areas}

Significant advances in electropolymerization areas during the 1990's are certain to facilitate the application of the sensors to different analytical areas. To date, electropolymerized films have been widely used for clinical and environmental detection purpose. 


\subsection{Electropolymerized films for clinical monitoring}

Electrochemical sensors in clinical assay was developed from 1962 by Clark and Lyons who used the glucose oxidase (GOx) enzyme to construct an amperometric electrode for dissolved oxygen detection [14]. From that time, the application of electrochemical sensors to determine the concentration of substances and other parameters of biological interest has represented a rapidly expanding field of instrument. The electrochemical sensors have been widely used in clinical analysis because of their high sensitivity and selectivity, portable field-based size, rapid response time and low-cost. Some of these sensor devices have been routinely used in clinical, industrial, environmental, and agricultural areas. Many works and reviews related on this area have been reported. Lakshmi D et al has reviewed the application of electrochemical sensors for uric acid detection in mixed and clinical samples[15]. Ronkainen et al reviewed the application of electrochemical biosensors from two points: biocatalyst and affinity [16].

Since the original work reported by Diaz et al. [17], the films prepared by electropolymreization method have attracted considerable interest due to their versatility. Polymers have gain considerable interest in the clinical analysis area because of their unique and biochemical properties. In 1992, Davies et al have extensively reviewed the application of the polymer membranes in clinical sensor application [18]. In this work, the authors were concerned with the relationship between the polymer design and the proposed application. They highlighted the permeability, permselectivity and transmembrane potential of the polymer membranes and the role of polymer membranes as matrices for the immobilization of reactive chemical and biological agents. Cosnier reviewed the application of the electropolymerized films on the construction of affinity sensor[19]. He compared the different strategies for the immobilization of biomolecules on electropolymerized films to construct affinity sensors which can be used as clinical sensors. Table 1 [20-52] summarized the numerous of recent applications in clinical areas based on the electropolymerized films. The information on the analytes, the polymer films, and the characters of the sensors has been listed.

Non-conductive polymer from polyphenylenediamines has been used as a matrix for the entrapment of enzymes. Glucose oxidase has been caged into the microtubule structures of polycarbonate membrane by using poly (1,3- phenylenediamine) to fill the pores. The sensitivity of the sensor increased 60 times [23]. Different techniques for the electropolymerization of 1,2-, 1,3- and 1,4-phenylenediamine, such as cyclic voltammetry and chronoamperometry, were compared by Currulli et al [53]. When heparin was coimmobilized with glucose oxidase during the electropolymerization of a non-conductive poly (1,2- phenylenediamine) film, an implantable glucose biosensor could be constructed [54]. This sensor could prevent the fibrin formation and clotting when the glucose sensor was exposed to blood.

Phenol and its derivative have also been widely used for clinical analysis. The electropolymerization of phenol derivatives is similar to that of phenol. We reported the polymerization of the acid chrome blue $\mathrm{K}$ on a glassy carbon electrode by cyclic viltammetric method in $0.05 \mathrm{M} \mathrm{pH} 7.0$ phosphate buffer solution in the potential range from $-0.4 \mathrm{~V}$ to $1.5 \mathrm{~V}$ at the scan range of $100 \mathrm{mV} / \mathrm{s}$ by 25 cycles [28]. This film can be used to separate the electrochemical response of dopamine (DA), ascorbic acid (AA) and uric acid (UA). Under the optimum conditions, the calibration curves for DA, AA and UA were obtained in the range of $1.0-200.0,50.0-1000.0$ and $1.0-120.0 \mu \mathrm{M}$, respectively. Both poly 


\begin{tabular}{|c|c|c|c|}
\hline analyte & monomer & $\begin{array}{l}\text { linearity or detection } \\
\text { limit }\end{array}$ & Ref \\
\hline \multirow{5}{*}{ glucose } & toluidine blue $\mathrm{O}$ & $0.1-1.2 \mathrm{mM}$ & 20 \\
\hline & preoxidized catecholamines & $0.3 \mu \mathrm{M}$ & 21 \\
\hline & $\begin{array}{l}\text { thioaniline functionalized gold } \\
\text { nanoparticle }\end{array}$ & $0-200 \mathrm{mM}$ & 22 \\
\hline & 1,3-phenylenediamine & $0.25 \mu \mathrm{M}-18 \mathrm{mM}$ & 23 \\
\hline & thioaniline-modified glucose oxidase & & 24 \\
\hline \multirow{4}{*}{ dopamine } & N-methylpyrrole & $0.1-10 \mu \mathrm{M}$ & 25 \\
\hline & aniline/gold nanoparticles & $3-115 \mu \mathrm{M}$ & 26 \\
\hline & 1-aminoanthracene & $0.56-100 \mu \mathrm{M}$ & 27 \\
\hline & acid chrome blue $\mathrm{K}$ & $1.0-200.0 \mu \mathrm{M}$ & 28 \\
\hline $\begin{array}{l}\text { prostate specific } \\
\text { antigen }\end{array}$ & $\begin{array}{c}\text { poly(1,2-diaminobenzene) as the template } \\
\text { for the electropolymerization of } \\
\text { polyaniline }\end{array}$ & $1-100 \mathrm{pg} / \mathrm{mL}$ & 29 \\
\hline \multirow{2}{*}{ uric acid } & 3-aminophenol & & 30 \\
\hline & 2-aminophenol & $0.5-0.9 \mathrm{mM}$ & 31 \\
\hline \multirow{7}{*}{ DNA } & \multirow{3}{*}{ pyrrole } & & 32 \\
\hline & & $3.7-370 \mathrm{nM}$ & 33 \\
\hline & & $0.16-3.5 \mathrm{fmol}$ & 34 \\
\hline & ferrocene-functionalized pyrrole & $0.1-200 \mathrm{nM}$ & 35 \\
\hline & $\begin{array}{l}\text { gold nanoparticles/p-aminobenzoic } \\
\text { acid/carbon nanotubes }\end{array}$ & $1.0 \mathrm{fmol}-50 \mathrm{nM}$ & 36 \\
\hline & gold nanoparticles/L-lysine & $0.1-10 \mathrm{fmol}$ & 37 \\
\hline & $\begin{array}{c}\text { silver nanoparticles/3-(3-pyridyl) acrylic } \\
\text { acid/carbon nanotubes }\end{array}$ & $9.0 \mathrm{fmol}-9.0 \mathrm{nM}$ & 38 \\
\hline leptin & $\begin{array}{c}\text { Au-pyrrole propylic acid-pyrrole } \\
\text { nanocomposite }\end{array}$ & $10-100000 \mathrm{ng} / \mathrm{mL}$ & 39 \\
\hline Human IgG & pyrrole-3-carboxylic acid & & 40 \\
\hline urea & styrene sulphonate-aniline & $0-75 \mathrm{mM}$ & 41 \\
\hline hemoglobin & pyrrole-gold nanoparticles & $60-180 \mu \mathrm{g} / \mathrm{mL}$ & 42 \\
\hline Myeloperoxidase & \begin{tabular}{|c|} 
o-phenylenediamine/multi-wall carbon \\
nanotubes -ionic liquid/gold nanoparticles
\end{tabular} & $0.25-350 \mathrm{ng} / \mathrm{mL}$ & 43 \\
\hline $17-\beta$ estradiol & $\begin{array}{c}\text { 3,4-ethylenedioxylthiopene/gold } \\
\text { Nanocomposite }\end{array}$ & & 44 \\
\hline \multirow{4}{*}{ nitric oxide } & eugenol or o-phenylenediamine & & 45 \\
\hline & poly(toluidine blue) & $0.18-86 \mu \mathrm{M}$ & 46 \\
\hline & $\begin{array}{l}\text { m-phenylenediamine, } 23- \\
\text { diaminonaphthalene, and } \\
\text { 5-amino-1-naphthol polymers }\end{array}$ & From $\mathrm{nM}$ to $\mu \mathrm{M}$ & 47 \\
\hline & meldola blue/chitosan & $10 \mathrm{nM}-600 \mu \mathrm{M}$ & 48 \\
\hline cholesterol & 2-mercaptobenzimidazole & $5-30 \mu \mathrm{M}$ & 49 \\
\hline \multirow{2}{*}{$\begin{array}{c}\text { nicotinamide } \\
\text { adenine dinucleotide }\end{array}$} & phenothiazine & $70 \mathrm{nM}$ & 50 \\
\hline & pyronin B & $1.0-500 \mu \mathrm{M}$ & 51 \\
\hline interleukin 5 & $\begin{array}{l}\text { pyrrole-pyrrolepropylic acid-gold } \\
\text { nanocomposite }\end{array}$ & $10 \mathrm{fg} / \mathrm{mL}$ & 52 \\
\hline
\end{tabular}

Table 1. Examples of electropolymerized films for clinical analysis 
(3-aminophenol) film [30] and poly (2-aminophenol) [31] film have been used for the selectively detection of uric acid. The poly (2-aminophenol) film was electrochemically prepared on $\mathrm{Pt}$ electrodes at a constant potential of $0.3 \mathrm{~V}$ from a deoxygenated aqueous solution of monomer dissolved in $0.1 \mathrm{M} \mathrm{KCl}$. This film modified electrode allows the penetration of large amounts of uric acid while blocking the electrochemical activity of ascorbic acid in the potential region examined.

\subsection{Electropolymerized film for environmental monitoring}

Electrochemical sensors play very important roles in the protection of our environment. They can monitor the pollutant on-site and address some other environmental needs. Several electrochemical devices, such as $\mathrm{pH}$ - or oxygen electrodes based on the polymerized films, have been used routinely for years in environmental analysis. The electropolymerized pyrrole [55,56], aniline, thiophene, benzene derivatives and others $[57,58]$ have been used for the preparation of $\mathrm{pH}$ chemical sensors. Herlem, $\mathrm{G}$ et al prepared the polyglycine-like thin film on platinum electrode by anodic oxidation. The film can be used as a $\mathrm{pH}$ sensor in the $\mathrm{pH}$ range 2-12 because of the proton affinity towards amino groups of polyglycine [59].

\begin{tabular}{|c|c|c|c|}
\hline Analyte & monomer & linearity or detection limit & Ref \\
\hline \multirow{3}{*}{$\mathrm{Hg}^{2+}$} & 2-mercaptobenzothiazole & $1.0-160.0 \mathrm{nM}$ & 62 \\
\hline & 2,6-diaminopyridine & $10 \mu \mathrm{M}-0.1 \mathrm{M}$ & 63 \\
\hline & 3-methylthiophene & $1.4 \mu \mathrm{g} / \mathrm{L}$ & 64 \\
\hline \multirow{4}{*}{ nitrite } & $\begin{array}{c}\text { methylene blue-carbon nanotubes- } \\
\text { ionic liquid }\end{array}$ & $0.5-67.9 \mu \mathrm{M}$ & 65 \\
\hline & carbon nanotube-anillin & $0.2 \mu \mathrm{M}-3.1 \mathrm{mM}$ & 66 \\
\hline & pyrrole & $10 \mu \mathrm{M}-1 \mathrm{mM}$ & 65 \\
\hline & functionalized thiadiazole & $0.05-16 \mu \mathrm{M}$ & 68 \\
\hline ammonia & pyrrole & $10-200 \mu \mathrm{M}$ & 69 \\
\hline $\mathrm{Ca}^{2+}$ & melatonin & $6.2 \times 10^{-7}-1.0 \times 10^{-4} \mathrm{M}$ & 70 \\
\hline \multirow[t]{2}{*}{$\mathrm{Cu}^{2+}$} & $\begin{array}{l}\text { 2-aminothiazole)-multi-walled } \\
\text { carbon nanotubes }\end{array}$ & $0.1-20 \mu \mathrm{M}$ & 71 \\
\hline & pyrrole & $50 \mathrm{nM}-0.01 \mathrm{M}$ & 72 \\
\hline \multirow[t]{2}{*}{ sulfite } & $\begin{array}{l}\text { copper salen (salen=N,N'- } \\
\text { ethylenebis(salicylideneiminato)) }\end{array}$ & $4.0-69 \mu \mathrm{M}$ & 73 \\
\hline & aniline & $0.006-5 \mathrm{mM}$ & 74 \\
\hline methyl-parathion & \multirow{2}{*}{ para-phenylenediamine } & \multirow{2}{*}{0.01 to $10 \mathrm{mg} / \mathrm{L}$} & \multirow{2}{*}{75} \\
\hline para-nitrophenol & & & \\
\hline microbial & $\begin{array}{c}\text { 4-(2,5-di(thiophen-2-yl)-1H-pyrrol- } \\
\text { 1-yl)benzenamine (SNS-NH2) } \\
\text { polymer }\end{array}$ & $0.1-2.5 \mathrm{mM}$ & 76 \\
\hline chloride & 3-octylthiophene & $10^{-8}-10^{-1} \mathrm{M}$ & 77 \\
\hline 4-nitrophenol & carmine & $50 \mathrm{nM}-10 \mu \mathrm{M}$ & 78 \\
\hline
\end{tabular}

Table 2. Examples of electropolymerized films for environmental analysis 
The scope of the electropolymerized films have also been expanded towards a wide range of organic and inorganic contaminants including pesticides, polychlorinated biphenyls, and heavy metals. A new kind of polymer monomer, bis(terthiophene)-appended uranylsalophen complex, comprising N,N'-bis[4-(5,2':5',2"-terthiophen-3'-yl)salicylidene]-1,2ethanediamine-uranyl complexes (TUS), has been modified on a glassy carbon electrode by electrochemical polymerizations. This polymer film has both the functionality of ion-toelectron transducers (solid contact) and Lewis-acidic binding sites to construct a monohydrogen phosphate (MHP) ion-selective electrode (ISE). The detection limit was down to $10^{-5} \mathrm{M}$ and the response time is less than $5 \mathrm{~s}$ [60]. In some cases, the polymers acted as the matrix for the immobilization of enzyme for environmental analytical application. Chen et al reported the entrapment of glucose oxidase into poly-(L-noradrenalin) films (PNA). They studied the inhibition effects of $\mathrm{Hg}^{2+}, \mathrm{Cu}^{2+}$, and $\mathrm{Co}^{2+}$ on the activity of glucose oxidase. The electrosynthesized PNA matrix to entrap GOX for an inhibitive assay of Ag+ shows the lowest competitive affinity to heavy metal ions and gives the highest sensitivity, so it can be used for $\mathrm{Ag}^{+}$detection61. The applications of the electropolymerized films applied for environmental monitoring were listed in Table 2 [62-78].

\section{Conclusion and future perspective}

There has been an enormous increase of the preparation and application of the polymer films in analytical areas. Some of the advances and fields of the electropolymerized films have been outlined in the review. The electropolymerization methods have important advantages over the conventional techniques for the modification and preparation of microelectrodes, permitting the regulation of the spatial location and selective control of the film properties. Selective immobilization of biomoleculars in array of microelectrodes can be implanted in biological tissues for the simultaneous detection of several compounds. Minimization arrays, fast responding electrochemical sensors and on-line detection are the developing tendency of the electropolymerized films in sensor areas. Some progress will be necessary to achieve the appearance of the commercial electrochemical sensors based on the electropolymerized films. A lot of future research into the development of new polymer films by electrochemical method can be expected.

\section{Acknowledgements}

We greatly appreciate the support of the National Natural Science Foundation of China (Nos. 20705030, 20875081, 21075107), 863 Program Foundation (2009AA03Z331), the Foundation of Jiangsu Key Laboratory of Environmental Material and Engineering (K08021) and the Postdoctoral Science Foundation of China (20090461161).

\section{References}

[1] B.J. Privett, J.H. Shin, M.H. Schoenfisch, Electrochemical Sensors, Analytical Chemistry 82 (2010) 4723-4741. 
[2] A. Ramanavicius, A. Ramanaviciene, A. Malinauskas, Electrochemical sensors based on conducting polymer- polypyrrole, Electrochimica Acta 51 (2006) 60256037.

[3] H. Peng, L.J. Zhang, C. Soeller, J. Travas-Sejdic, Biomaterials 30 (2009) 21322148.

[4] C.Y. Wang, J. Guan, Q.S. Qu, G.J. Yang, X.Y. Hu, Combinatorial Chemistry \& High Throughput Screening 10 (2007) 595-603.

[5] Z. Ežerskis, Z. Jusys, Journal of Applied Electrochemistry 31 (2001) 1117-1124.

[6] M.R. Mahmoudian, Y. Alias, W.J. Basirun, Materials Chemistry and Physics 124 (2010) 1022-1028.

[7] N.B. Tahar, A. Savall, Electrochimica Acta 55 (2009) 465-469.

[8] Y. Matsushita, T. Sekiguchi, R. Ichino, K. Fukushima, Journal of Wood Science 55 (2009) 344-349.

[9] R. Ciriello, A. Guerrieri, F. Pavese, A. M. Salvi, Analytical and Bioanalytical Chemistry 392 (2008) 913-926.

[10] J. Guan, Z.X. Wang, C.Y. Wang, Q.S. Qu, G.J. Yang, X.Y. Hu, International Journal of Electrochemical Science 2 (2007) 572-582.

[11] C.Y. Wang, Q.X. Liu, X.Q. Shao, X.Y. Hu, Analytical Letters 40 (2007) 689-704.

[12] C.Y. Wang, Y.D. Mao, D.Y. Wang, G.J. Yang, Q.H. Qu, X.Y. Hu, Bioelectrochemistry 72 (2008) 107-115.

[13] Q. Xu, M. Sun, Q.X. Du, X.J. Bian, D. Chen, X.Y. Hu, Current Pharmaceutical Analysis 5 (2009) 190-196.

[14] L.C. Clark, C. Lyons, Annals of the New York Academy of Sciences 102 (1962) 29-\&.

[15] D. Lakshmi, M.J. Whitcombe, F. Davis, P.S. Sharma, B.B. Prasad, Electroanalysis 23 (2011) 305-320.

[16] N.J. Ronkainen, H.B. Halsall, W.R. Heineman, Chemical Society Reviews 39 (2010) 17471763.

[17] A F. Diaz, K. K. Kanazawa, G. P. Gardini, Journal of the Chemical Society, Chemical Communications (1979) 635-636

[18] M.L. Davies, C.J. Hamilton, S.M. Murphy, B.J. Tighe, Biomaterials 13 (1992) 971-978.

[19] S. Cosnier, Electroanalysis 17 (2005) 1701-1715.

[20] W.J. Wang, F. Wang, Y.L. Yao, S.S. Hu, K.K. Shiu, Electrochimica Acta 55 (2010) 70557060.

[21] C. Chen, Y.C. Fu, C.H. Xiang, Q.J. Xie, Q.F. Zhang, Y.H. Su, L.H. Wang, S.Z. Yao, Biosensors \& Bioelectronics 24 (2009) 2726-2729.

[22] O. Yehezkeli, R. Tel-Vered, S. Reichlin, I. Willner, Acs Nano 5 (2011) 2385-2391.

[23] M. Lee, Y. Son, J. Park, Y. Lee, Molecular Crystals and Liquid Crystals 492 (2008) 155164.

[24] O. Yehezkeli, Y.M. Yan, I. Baravik, R. Tel-Vered, I. Willner, Chemistry-a European Journal 15 (2009) 2674-2679.

[25] N.F. Atta, M.F. El-Kady, A. Galal, Analytical Biochemistry 400 (2010) 78-88.

[26] A.J. Wang, J.J. Feng, Y.F. Li, J.L. Xi, W.J. Dong, Microchimica Acta 171 (2010) 431436. 
[27] E.D. Troiani, R.C. Faria, Electroanalysis 22 (2010) 2284-2289.

[28] R. Zhang, G.-D. Jin, D. Chen, X.-Y. Hu, Sensors and Actuators B 138 (2009) 174181.

[29] A.C. Barton, F. Davis, S.P.J. Higson, Analytical Chemistry 80 (2008) 6198-6205.

[30] S. Kursun, A. Pasahan, B.Z. Ekinci, E. Ekinci, International Journal of Polymeric Materials 60 (2011) 365-373.

[31] S. Kursun, B.Z. Ekinci, A. Pasahan, E. Ekinci, Journal of Applied Polymer Science 120 (2011) 406-410.

[32] J.H. Jin, E.C. Alocilja, D.L. Grooms, Journal of Porous Materials 17 (2010) 169176.

[33] H. Peng, C. Soeller, M.B. Cannell, G.A. Bowmaker, R.P. Cooney, J. Travas-Sejdic, Biosensors \& Bioelectronics 21 (2006) 1727-1736.

[34] C.D. Riccardi, H. Yamanaka, M. Josowicz, J. Kowalik, B. Mizaikoff, C. Kranz, Analytical Chemistry 78 (2006) 1139-1145.

[35] H.Q.A. Le, S. Chebil, B. Makrouf, H. Sauriat-Dorizon, B. Mandrand, H. Korri-Youssoufi, Talanta 81 (2010) 1250-1257.

[36] Y.Z. Zhang, J. Wang, M.L. Xu, Colloids and Surfaces B-Biointerfaces 75 (2010) 179185.

[37] J. Wang, S.J. Zhang, Y.Z. Zhang, Analytical Biochemistry 396 (2010) 304-309.

[38] Y.Z. Zhang, K.Y. Zhang, H.Y. Ma, Analytical Biochemistry 387 (2009) 13-19.

[39] W. Chen, Y. Lei, C.M. Li, Electroanalysis 22 (2010) 1078-1083.

[40] R. Janmanee, A. Baba, S. Phanichphant, S. Sriwichai, K. Shinbo, K. Kato, F. Kaneko, Japanese Journal of Applied Physics 50 (2011) Part 3 Sp. Iss. SI, 01BK02.

[41] S.K. Jha, M. Kanungo, A. Nath, S.F. D'Souza, Biosensors \& Bioelectronics 24 (2009) 26372642.

[42] L. Qu, S.H. Xia, C. Bian, J.Z. Sun, J.H. Han, Biosensors \& Bioelectronics 24 (2009) 34193424.

[43] B. Liu, L.S. Lu, C.G. Liu, G.M. Xie, Acta Chimica Sinica 69 (2011) 438-444.

[44] R.A. Olowu, O. Arotiba, S.N. Mailu, T.T. Waryo, P. Baker, E. Iwuoha, Sensors 10 (2010) 9872-9890.

[45] B.A. Patel, M. Arundell, K.H. Parker, M.S. Yeoman, D. O'Hare, Analytical Chemistry 78 (2006) 7643-7648.

[46] Y.Z. Wang, S.S. Hu, Biosensors \& Bioelectronics 22 (2006) 10-17.

[47] J.H. Shim, H. Do, Y. Lee, Electroanalysis 22 (2010) 359-366.

[48] J. Njagi, J.S. Erlichman, J.W. Aston, J.C. Leiter, S. Andreescu, Sensors and Actuators BChemical 143 (2010) 673-680.

[49] A. Aghaei, M.R.M. Hosseini, M. Najafi, Electrochimica Acta 55 (2010) 15031508.

[50] Q. Gao, M. Sun, P. Peng, H.L. Qi, C.X. Zhang, Microchimica Acta 168 (2010) 299307.

[51] S.A. Kumar, S.L. Chen, S.M. Chen, Electroanalysis 21 (2009) 1379-1386.

[52] W. Chen, Z.S. Lu, C.M. Li, Analytical Chemistry 80 (2008) 8485-8492.

[53] A. Curulli, G. Palleschi, In Proceedings of The 2nd Workshop on Chemical Sensors and Biosensors (Mazzei, F. and Pilloton, R., eds), (2000) 439-444 
[54] J.Wang, L. Chen, S.B. Hocevar, B. Ogorevc, Analyst 125 (2000)1431-1434

[55] W. Prissanaroon-Ouajai, P.J. Pigram, R. Jones, A. Sirivat, Sensors and Actuators BChemical 138 (2009) 504-511.

[56] W. Prissanaroon-Ouajai, P.J. Pigram, R. Jones, A. Sirivat, Sensors and Actuators BChemical 135 (2008) 366-374.

[57] G. Herlem, B. Lakard, M. Herlem, B. Fahys, Journal of The Electrochemical Society 148 (2001) E435-E43

[58] R. Aoun, A. Yassin, M. El Jamal, A. Kanj, J. Rault-Berthelot, C. Poriel, Synthetic Metals 158 (2008) 790-795.

[59] G. Herlem, R. Zeggari, J.Y. Rauch, S. Monney, F.T. Anzola, Y. Guillaume, C. Andre, T. Gharbi, Talanta 82 (2010) 417-421.

[60] J. Kim, D.M. Kang, S.C. Shin, M.Y. Choi, S.S. Lee, J.S. Kim, Analytica Chimica Acta 614 (2008) 85-92.

[61] C. Chen, Q.J. Xie, L.H. Wang, C. Qin, F.Y. Xie, S.Z. Yao, J.H. Chen, Analytical Chemistry 83 (2011) 2660-2666.

[62] X.C. Fu, X. Chen, Z. Guo, C.G. Xie, L.T. Kong, J.H. Liu, X.J. Huang, Analytica Chimica Acta 685 (2011) 21-28.

[63] F. Bakhtiarzadeh, S. Ab Ghani, Electroanalysis 22 (2010) 549-555.

[64] H. Zejli, P. Sharrock, J. de Cisneros, I. Naranjo-Rodriguez, K.R. Temsamani, Talanta 68 (2005) 79-85.

[65] Y.H. Li, X.L. Liu, X.D. Zeng, X.Y. Liu, L. Tao, W.Z. Wei, S.L. Luo, Sensor Letters 8 (2010) 584-590.

[66] D.Y. Zheng, C.G. Hu, Y.F. Peng, S.S. Hu, Electrochimica Acta 54 (2009) 49104915.

[67] S. Aravamudhan, S. Bhansali, Sensors and Actuators B-Chemical 132 (2008) 623630.

[68] P. Kalimuthu, S.A. John, Electrochemistry Communications 11 (2009) 10651068.

[69] L. Zhang, F.L. Meng, Y. Chen, J.Y. Liu, Y.F. Sun, T. Luo, M.Q. Li, J.H. Liu, Sensors and Actuators B-Chemical 142 (2009) 204-209.

[70] X.P. Wu, W. Liu, H. Dai, G.N. Chen, Electrochemistry Communications 11 (2009) 393396.

[17] H. Zhao, Z.J. Wu, Y. Xue, Q.A. Cao, Y.J. He, X.J. Li, Z.B. Yuan, Journal of Nanoscience and Nanotechnology 11 (2011) 3381-3384.

[72] A.R. Zanganeh, M.K. Amini, Sensors and Actuators B-Chemical 135 (2008) 358365.

[73] T.R.L. Dadamos, M.F.S. Teixeira, Electrochimica Acta 54 (2009) 4552-4558.

[74] B. Bahmani, F. Moztarzadeh, M. Hossini, M. Rabiee, M. Tahriri, M. Rezvannia, M. Alizadeh, Asian Journal of Chemistry 21 (2009) 923-930.

[75] I. Tapsoba, S. Bourhis, T. Feng, M. Pontie, Electroanalysis 21 (2009) 1167-1176.

[76] S. Tuncagil, D. Odaci, E. Yidiz, S. Timur, L. Toppare, Sensors and Actuators B-Chemical 137 (2009) 42-47.

[77] P. Sjoberg-Eerola, J. Nylund, J. Bobacka, A. Lewenstam, A. Ivaska, Sensors and Actuators B-Chemical 134 (2008) 878-886. 
[78] C.Y. Li, Journal of Applied Polymer Science 103 (2007) 3271-3277. 


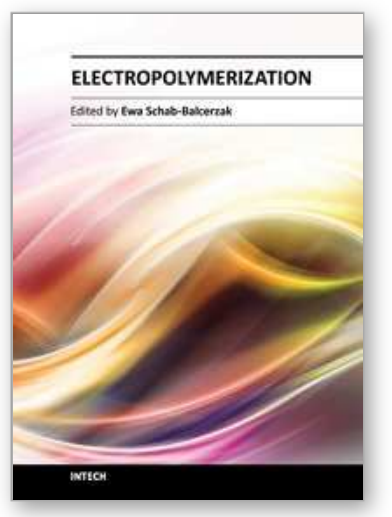

\author{
Electropolymerization \\ Edited by Dr. Ewa Schab-Balcerzak
}

ISBN 978-953-307-693-5

Hard cover, 214 pages

Publisher InTech

Published online 22, December, 2011

Published in print edition December, 2011

In recent years, great focus has been placed upon polymer thin films. These polymer thin films are important in many technological applications, ranging from coatings and adhesives to organic electronic devices, including sensors and detectors. Electrochemical polymerization is preferable, especially if the polymeric product is intended for use as polymer thin films, because electrogeneration allows fine control over the film thickness, an important parameter for fabrication of devices. Moreover, it was demonstrated that it is possible to modify the material properties by parameter control of the electrodeposition process. Electrochemistry is an excellent tool, not only for synthesis, but also for characterization and application of various types of materials. This book provides a timely overview of a current state of knowledge regarding the use of electropolymerization for new materials preparation, including conducting polymers and various possibilities of applications.

\title{
How to reference
}

In order to correctly reference this scholarly work, feel free to copy and paste the following:

Xu Qin, Hu Xiao-Ya and Hao Shi-Rong (2011). Electrochemical Sensors Based on Electropolymerized Films, Electropolymerization, Dr. Ewa Schab-Balcerzak (Ed.), ISBN: 978-953-307-693-5, InTech, Available from: http://www.intechopen.com/books/electropolymerization/electrochemical-sensors-based-onelectropolymerized-films

\section{INTECH}

open science | open minds

\section{InTech Europe}

University Campus STeP Ri

Slavka Krautzeka 83/A

51000 Rijeka, Croatia

Phone: +385 (51) 770447

Fax: +385 (51) 686166

www.intechopen.com

\section{InTech China}

Unit 405, Office Block, Hotel Equatorial Shanghai No.65, Yan An Road (West), Shanghai, 200040, China 中国上海市延安西路65号上海国际贵都大饭店办公楼405单元 Phone: +86-21-62489820

Fax: $+86-21-62489821$ 
(C) 2011 The Author(s). Licensee IntechOpen. This is an open access article distributed under the terms of the Creative Commons Attribution 3.0 License, which permits unrestricted use, distribution, and reproduction in any medium, provided the original work is properly cited. 